\title{
The Concurrence of Multiple Sclerosis and Amyotrophic Lateral Sclerosis
}

\author{
Walter J. Hader, Bohdan Rozdilsky and Cheranada P. Nair
}

\begin{abstract}
We report the clinical and pathological findings of the unusual combination of two idiopathic central nervous system diseases, multiple sclerosis and amyotrophic lateral sclerosis in a 56 year old physician with a twenty-seven year history of a disease initially characterized by relapses and remissions, followed by an eight year quiescent period. During the last year of life there was rapid deterioration with development of generalized weakness, atrophy, weight loss and fasciculations of body and tongue, and associated difficulty with swallowing and sudden respiratory failure. The autopsy confirmed characteristic "burned out" plaques of multiple sclerosis and anterior horn cell and axonal degeneration of amyotrophic lateral sclerosis.
\end{abstract}

RÉSUMÉ: Coexistence de sclérose en plaques et de sclérose latérale amyotrophique Nous rapportons les données cliniques et pathologiques chez un médecin de 56 ans avec une histoire datant de 27 ans qui s'est manifestée au début par des rechutes et des rémissions et plus tard par une période tranquille de 8 ans. Chez ce patient nous avons trouvé une rare association de deux maladies du système nerveux central: la sclérose en plaques (SEP) et la sclérose latérale amyotrophique (SLA). Au cours de la dernière année de sa vie, on nota une détérioration rapide avec faiblesse généralisée, atrophie, perte de poids, fasciculations du corps et de la langue et difficultés de déglutition, le tout se terminant par un collapsus respiratoire soudain. L'autopsie confirma d'anciennes plaques caractéristiques du SEP ainsi qu'une dégénérescence des cellules de la corne antérieure et une dégénérescence axonale comme dans la SLA.

Can. J. Neurol. Sci. 1986; 13:66-69

The occurrence of two primary idiopathic central nervous system diseases in the same person is uncommon. Multiple sclerosis (MS) is a multifocal demyelinating white matter disease characterized by relapsing and remitting disturbances of motor, sensory or excretory functions in the young adult that may occur over long periods of time. This disease of unknown etiology affects young adults with an average age of onset of 29 years. The pathology of the disease is quite characteristic with the plaque formation in the central nervous system. The diagnosis of clinical definite multiple sclerosis rests on the history and examination. ${ }^{1}$

Amyotrophic lateral sclerosis (ALS) is a progressive degenerative disorder of the cell bodies and axons of the motor neurons in the brain and spinal cord characterized by upper and lower motor neuron signs and symptoms. ${ }^{2}$ Cases of multiple sclerosis which simulate amyotrophic lateral sclerosis have been described in the literature..$^{3.7}$ We report a patient who developed clinical features separated temporally and consistent with separate diagnoses of MS and ALS, both occurring in the same individual.

\section{CASE Report}

This 56 year old physician first developed neurological symptoms at age 29 with numbness of the right side of the face and left side of the chest lasting for about 10 days. One year later, in June 1957, he felt a tight waist belt sensation with paresthesiae and numbness of the scrotum and rectal area, and impairment of position sense in the feet, occurring two days following immunization against poliomyelitis. Numbness and tingling of the soles of the feet extended to the nipple level over the next five days. The neurological deficits included asymmetric tendon reflexes, the left being more brisk than the right, loss of vibration sense to the iliac crest level, impairment of joint position sense at the toes, and absent plantar responses. The symptoms resolved in two months.

In April 1958 he developed a left retrobulbar neuritis which resolved in two weeks. During the next few months he complained of dizziness and diplopia on looking to the right. On examination there was pronounced nystagmus to the right with a rotary component, decrease in light touch in the lower extremities, impaired vibration sense in the feet and position sense loss in the toes. Remission occurred in one month.

In January 1960, the patient recorded that he "noticed numbness of the tips of the first three digits of the right hand, which extended gradually up the whole arm in three days, with associated marked

From the Departments of Rehabilitation Medicine, Pathology (Neuropathology), University Hospital, Saskatoon, Saskatchewan, and the Plains Health Centre, Regina, Saskatchewan 
clumsiness and a definite intention tremor." Numbness of the right axilla and chest and hyperesthesiae of the right ear and scalp occurred shortly after. On examination there was mild nystagmus to the left with impaired coordination and vibration sense in the fingers of the right hand.

Repeat neurological examinations in 1963 and 1967 were recorded as normal. The patient had experienced minor exacerbations, periods of mild unsteadiness, and paresthesiae of fleeting nature but remained very active.

In May 1972, he complained of paresthesiae in the right mid-thoracic region and weakness of the right leg aggravated when running. Examination revealed mild cerebellar incoordination in both upper limbs, slight weakness of the right hip flexors and dorsiflexors of the right foot, and increased tendon reflexes in the right leg with a right extensor plantar response. Position and vibration sense were impaired to the right midcalf level. In early 1980, the patient developed an episode of acute vertigo and ataxia of two months' duration, with staggering gait and tinnitus in the left ear.

In 1981, the patient began to experience easy fatiguability and a tendency for the left leg to give way. In early 1982 he could not participate in the sport of curling and had difficulty walking 60 yards. He developed urgency, frequency and occasional incontinence. Neurological evaluation in July 1982 revealed normal power, tone, and coordination, increased stretch reflexes on the left, exaggerated left abdominal reflexes, and bilateral extensor planter responses. Vibration sense was reduced distally in both legs.

In September 1982, weakness of the legs commenced with easy fatigue and a sensation of heaviness. He noted mild dysphagia, hoarseness of voice, and wasting of the left thenar and dorsal interosseous muscles and a weight loss of $12 \mathrm{~kg}$. over the past year. A few fasciculations were noticed around the shoulder regions. All reflexes were brisk with a left extensor plantar response elicited. The abdominal reflexes could not be obtained. There was weakness of the dorsiflexors of the left foot. The CPK was 589 units $/ \mathrm{L}(\mathrm{N}<150)$ and remained elevated at 730 units $/ \mathrm{L}$ when repeated one month later. The initial EMG showed normal motor and sensory conduction studies.

The weakness progressed and two months later increased fasciculations and mild atrophy were noted around the shoulder regions. Repeat EMG revealed fibrillations and fasciculations in the right deltoid and right triceps muscles; the interference pattern was reduced, and some motor units were of prolonged duration, high amplitude and polyphasic.

The CSF protein was 0.24 grams $/ \mathrm{L}$; the $\mathrm{IgG}$ was $20 \mathrm{mgm} / \mathrm{L}$ (normal 6-86); lgG albumin ratio was 0.08 (normal $0.07-0.25$ ). An oil contrast myelogram was normal.

Over the next 4 months he developed increasing muscle weakness and atrophy and widespread fasciculations of the body and tongue. He died of sudden respiratory failure in April 1983, 27 years after his first neurologic symptoms.

\section{Pathological Findings}

At post-mortem examination coronal sections of the occipital lobes showed a sharply demarcated greyish discoloration and semi-translucency around the posterior horns of the lateral ventricles, an appearance typical of multiple sclerosis plaques. The remaining white matter of the cerebral hemispheres, the basal ganglia, the diencephalic structures, brainstem and cerebellum were all unremarkable. The spinal cord was slightly atrophic, especially in the cervical segments. The anterior nerve roots were slightly atrophic and partly demyelinated.

On microscopic examination the periventricular lesions were inactive plaques and "shadow plaques" of demyelination, characterized by isomorphous gliosis supporting hypertrophic fibrous astrocytes but devoid of oligodendroglial cells (Figure 1). With silver stains (Bodian) there was good preservation of axis cylinders within the plaques (Figure 2). At the upper cervical level a large plaque of demyelination and gliosis was located asymmetrically in the posterior columns, involving almost the entire right and the adjacent portion of the left column (Figure 3). There was no active inflammatory reaction within this lesion. An elongated focus of gliosis and demyelination was found in the posterior columns of the lumbosacral segments of the cord.

There was no definite loss of giant pyramidal cells of Betz type in the fifth cortical layer in the sensorimotor cortex of either cerebral hemisphere. The nuclei of motor cranial nerves, with the exception of the 12th nerve nuclei, were well preserved.

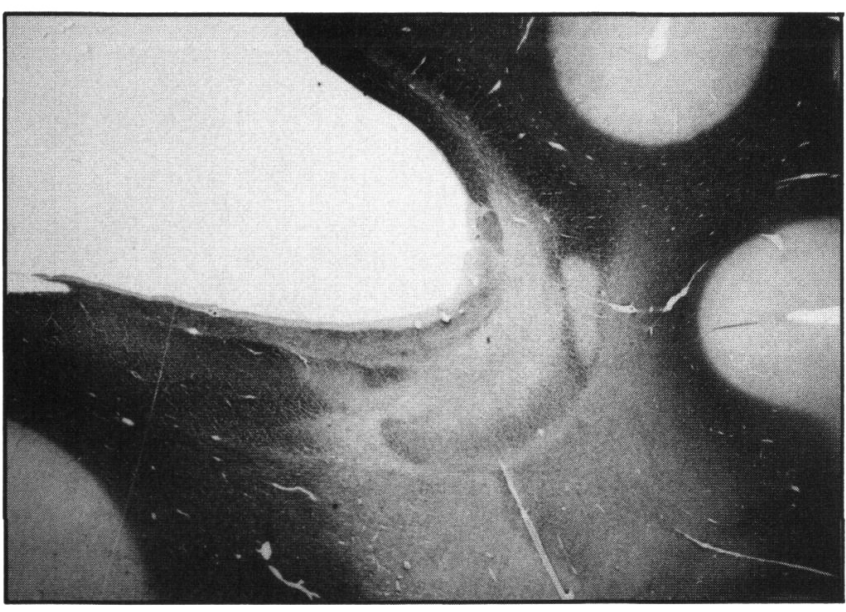

Figure I - Plaques of multiple sclerosis type around posterior horn of lateral ventricle. Page's Erichrome Myelin stain, magn. $\times 30$.

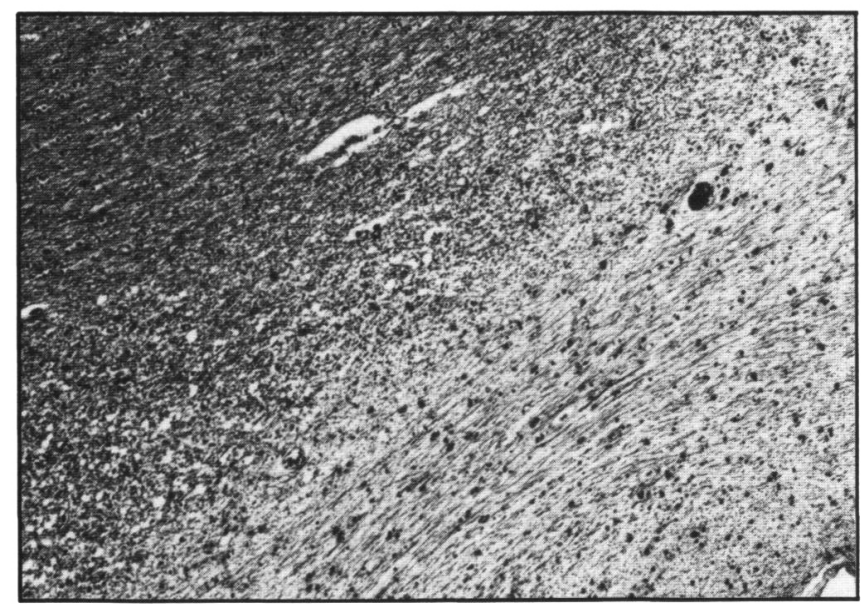

Figure 2-Periventricular plaque showing some preservation of axis cylinder within glial scar tissue in the right and lower portion of the field. Bodian Silver stain, magn. $\times 150$.

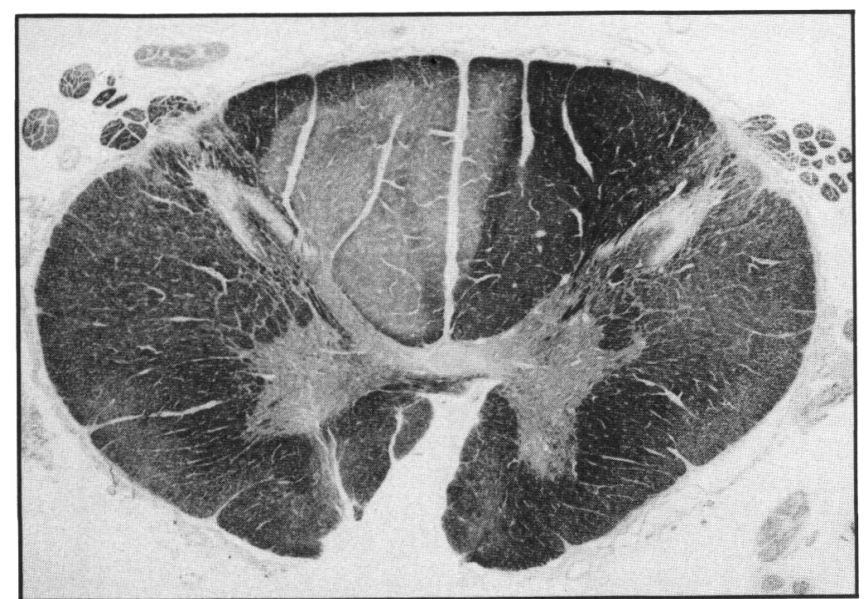

Figure 3-Plaque of demyelination involving posterior columns of upper cervical cord and slight paleness of the lateral columns. Page's Erichrome Myelin stain, magn. $\times 10$. 


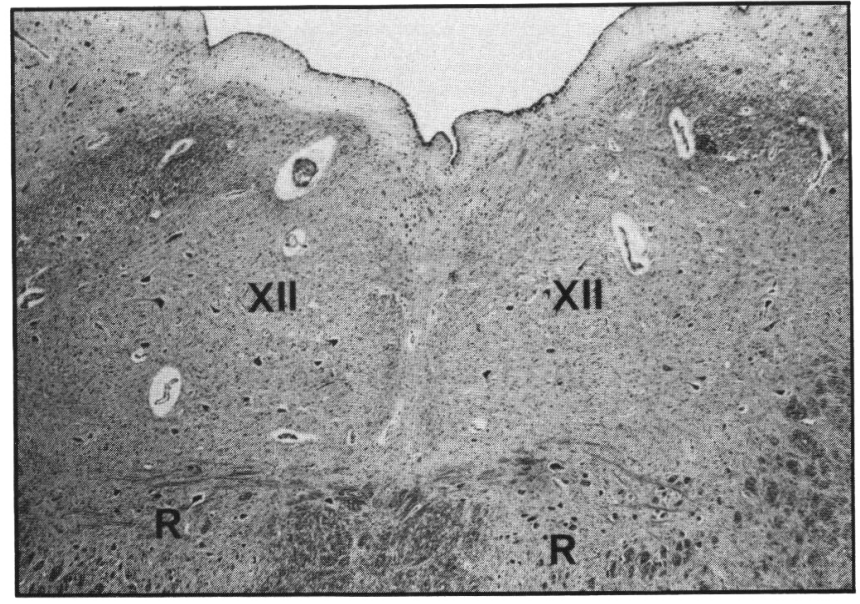

Figure 4-Partial loss of nerve cells in the twelve nerve nucleus (XII). Note intact Roller's nuclei $(R)$. Page's Myelin with C.V. counterstain. magn. $\times 30$.

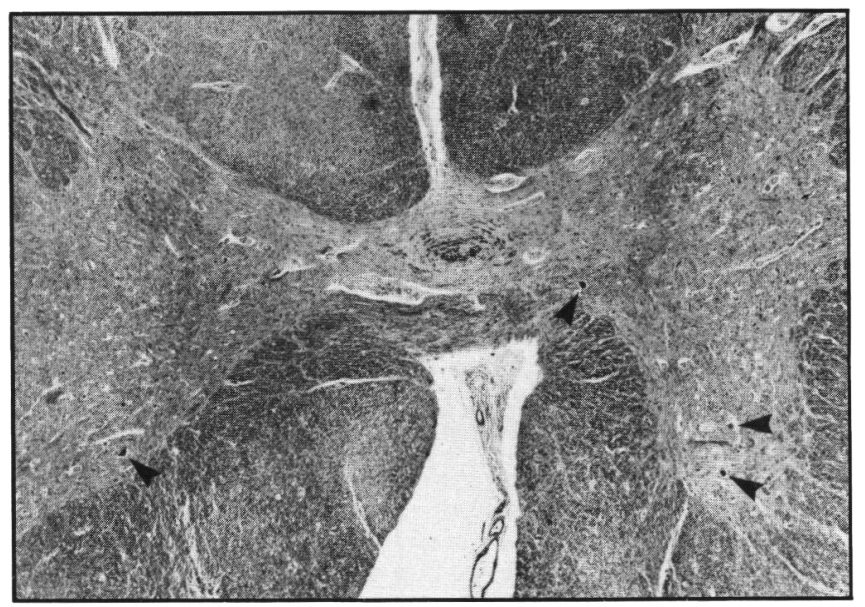

Figure 5 - Spinal cord at the upper cervical level with only a few intact motor nerve cells (arrowheads; the remaining degenerating nerve cells are shrunken and atrophic). Page's Myelin with C.V. counterstain. magn. $X$ 30 .

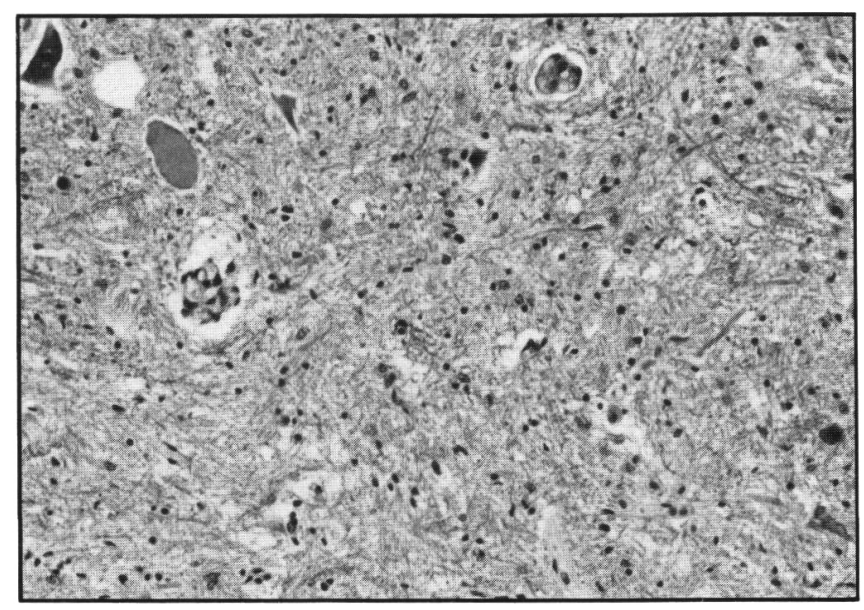

Figure 6 - Loss of motor nerve cells in a lumber segment of cord, chronic degenerative changes and an axonal swelling. H.E. magn. $\times 150$.
The hypoglossal nerve nuclei were partially depleted of nerve cells (Figure 4) and many surviving cells were atrophic. The loss of anterior horn cells was variable and diffuse throughout the entire length of the cord, with almost complete loss in some sections (Figure 5); the loss of nerve cells was associated with sponginess and gliosis of the background tissue (Figure 6). Only a few axonal swellings were noted. The pyramidal tracts showed only slight paleness in myelin stained sections, more severe in the thoracic and lumbosacral segments.

\section{Discussion}

The clinical and pathological features in our case suggest that the patient had two separate diseases, MS and ALS. Cases of multiple sclerosis simulating amyotrophic lateral sclerosis were described by Charcot, ${ }^{3}$ Pitres, ${ }^{4}$ Dejerine, ${ }^{5}$ Bouchaud ${ }^{6}$ and Thomas. ${ }^{7}$ Extensive muscular atrophy in multiple sclerosis mainly in the upper extremities, has been described in earlier literature by several authors. ${ }^{8-14}$

Focal muscular atrophy was noted by Muller ${ }^{15}$ and $\mathrm{Abb}$ and Schaltenbrand ${ }^{16}$ in their cases of MS. Charcot ${ }^{3}$ in two autopsy cases attributed the progressive atrophy to "sclerosed foci extending to nerve cells of the anterior cornua of the grey matter.' In autopsy cases cited by Davison, ${ }^{17}$ a similar destruction of anterior horn cells was found mainly in the lower cervical regions.

One case reported by Probst $^{9}$ might have suggested a combination of MS with ALS as "nerve cell bodies of the anterior horn cells were lost or degenerating whereas no sclerotic foci were found in the spinal cord." He attributed the focal loss of cells restricted to the highest level of the cord to the "summation of action of several demyelinating MS plaques in the brainstem on the same (pyramidal) tracts."

Axonal swellings in the anterior horns and brainstem nuclei are more common in early stages of ALS as reported by Carpen$\operatorname{ter}^{18}$ and only a few were noted in our case. The anterior nerve roots were atrophic and partly demyelinated, both features described by Hanyu, ${ }^{19}$ Sobve, ${ }^{20}$ and Sobve. ${ }^{21}$ There was no evidence of 'onion bulb' formations in the central plaques or nerve roots, findings which also occur in the peripheral nerves. ${ }^{22-24}$ A reduction in myelin thickness in peripheral nerves has been reported by Pollock ${ }^{25}$ in 8 of 10 cases of MS.

In our case there was degeneration and loss of motor nerve cells in the twelfth nerve nuclei and the anterior horn cells throughout the entire length of the spinal cord without any relationship to the two MS plaques, a finding which may justify a diagnosis of co-existing demyelinating and motor neuron disease.

Fasciculations have not been mentioned in the extensive works of Muller, ${ }^{15}$ Abb, ${ }^{16}$ Davison, ${ }^{17}$ and Nagler, ${ }^{26}$ and "fibrillation" involving the tongue and hand muscles in one patient (case 44 ) has been recorded by Thygesen. ${ }^{27}$ Kurtzke $^{28}$ recalls no other documented cases and states "fasciculations are almost enough to rule out this disease" (MS) and "even though the disease does destroy gray matter there is a rarity of fasciculations." McAlpine ${ }^{29}$ records focal paresis and muscular wasting with fasciculations, that may persist with subsequent atrophy but is rarely seen.

Fasciculations and widespread but minor atrophy with EMG evidence of denervation has been observed by Paty ${ }^{30}$ in a number of MS patients with acute spinal cord exacerbations. The subsequent recovery in these cases implied a temporary 
disturbance of function in anterior horn cells. Electrodiagnostic studies by Fisher and coworkers ${ }^{31.32}$ were entirely normal in eight of nine MS patients, suggesting that the atrophy of intrinsic muscles of the hands was due to a "central lesion". The elevation of the CPK seen in our patient has been described in rapidly advancing ALS. ${ }^{33}$

The sensory disturbances noted several times in the early course of the disease in this patient were likely due to the demyelinating disease. Although they were not recorded in the later stages of the illness, sensory symptoms are frequently noted in ALS. ${ }^{35-37}$

The combination of MS and ALS has been seen twice in the clinical experience of Tyler, ${ }^{34}$ but no post mortems have been performed. Noseworthy ${ }^{38}$ has recorded a case of multiple sclerosis preceded clinically by a motor radiculopathy. There is no indication of the combination of these two diseases in Breland' $s$ ' study of 54 cases of MS and 55 cases of ALS and the 50 year incidence study of ALS by Juergens. ${ }^{40}$

In the previously reported cases coincident muscular atrophy with multiple sclerosis has been explained by focal destruction of anterior horn cells by demyelinating plaques of MS. None have had a remitting disease (MS), with a quiescent period followed by rapidly progressive wasting disease (ALS) as occurred in our case. Therefore this likely represents chance occurrence of these two diseases.

\section{ACKNOWLEDGEMENTS}

The authors thank Dr. E. Alport, Dr. E. Ashenhurst, Dr. C. Cunning and Dr. A.F. Huston for clinical contributions. Beverly Atkinson provided secretarial assistance.

\section{REFERENCES}

1. Schumacher GA, Beebe G, Kibler RFet al. Problems of experimental trials of therapy in multiple sclerosis. Am MY Acad Sci 1965; 122: $522-568$.

2. Rowland LP. Diverse Forms of Motor Neuron Diseases. In: Rowland LP, ed. Advances in neurology. New York: Raven Press, 1982: 1-13.

3. Charcot JM. Lectures on diseases of nervous system. Translation by Sigerson G. 2nd edition. Philadelphia: HG Lea, 1879: 164.

4. Pitres A. Contribution à l'étude des anomalies de la sclérose en plaques disseminée. Rev de med 1877; 1: 893-908.

5. Déjèrine J. Études sur la sclérose en plaques cerebrospinale à forme de sclérose latéral amyotrophique. Rev de med 1884; 4: 193-212.

6. Bouchaud. Sclérose en plaques avec amyotrophies. J de neurol 1900; 5: 348-356.

7. Thomas A, Long E. Contribution à l'étude des scléroses de la moelle épinière. Comptes Rendus de la société de biologie (Paris) 1899; 11: 768-770.

8. Brauer L. Muskelatrophie bei Multipler Sklerose. Neurol Centralbl 1898; 17: 635-640.

9. Probst M. Zur Kenntnis der disseminierten Hirn-Rückenmarksklerose. Arch f Psychiat 1901; 24: 447-472.

10. Wegelin F. Ueber akut verlaufende Multipler Sklerose. Deutsche Ztschr f Nervenh 1906; 31: 313-327.

11. Schnitzler JG. Klinische Beitrage zur Kenntnis der Muskel-atrophien laufenden formen von multipler sklerose and chronische myelitis. Ztschr f d ges Neurol u Psychiat 1912; 12: 310-353.

12. Spiller WG. A report of two cases of multiple sclerosis with necropsy. Am J M Sc 1903; 125: 61-74.

13. Bau-Prussak S. Uber amyotrophische form der Multiplen Sklerose. Zenbralbl $f$ d ges Neurol u Psychiat 1930; 54: 495.

14. Burian U. Kasuistischer Beitrag zur Frage der psychischen Storungen bei Multipler Sklerose. Bonn 1932.
15. Muller R. Studies on disseminated sclerosis with special reference to symptomatology, course and prognosis. Acta Med Scand 1949; 133 suppl 222:1-214.

16. Abb L, Schaltenbrand G. Statistische untersuchengen zum problem der Multiplen Sklerose. II Mitteilung Das Krankheitsbild der Multiplen Sklerose. Dtsch Z Nervenheilk 1956: 174: 199-218.

17. Davison C., Goodhart SP, Lander J. Multiple Sclerosis and amyotrophies. Arch Neurol Psychiat (Chic) 1934: 31: 270-289.

18. Carpenter S. Proximal axonal enlargement in motor neuron disease. Neurol 1968; 18: 841-851.

19. Hanyu N, Oguchi K, Yanagisawa $\mathrm{N}$ et al. Degeneration and regeneration of central root motor fibers in amyotrophic lateral sclerosis. Morphometric studies of cervical central roots. J Neurol Sci 1982; 55: 99-115.

20. Sobue G, Matsuoka Y. Mukai E et al. Pathology of myelinated fibers in cervical and lumbar ventral spinal roots in amyotrophic lateral sclerosis. J Neurol Sci 1981; 50: 413-421.

21. Sobue G, Hashizume $Y$, Sahashi $K$ et al. Amyotrophic lateral sclerosis. Lack of central chromatolytic response of motor neurocytons corresponding to active axonal degeneration. Arch Neurol 1983; 40: 306-309.

22. Schoene WC, Carpenter S, Behan PO. Geschwind N. Onion bulb formations in the central and peripheral nervous system in association with multiple sclerosis and hypertrophic polyneuropathy. Brain 1977; 100: 755-773.

23. Rosenberg NL. Bourdette D. Hypertrophic neuropathy and multiple sclerosis. Neurol 1983: 33: 1361-1364.

24. Ro Yl, Alexander CB, Oh SJ. Multiple sclerosis and hypertrophic demyelinating peripheral neuropathy. Muscle Nerve 1983; 6: 312-316.

25. Pollock M, Calder C, Allpress S. Peripheral nerve abnormality in multiple sclerosis. Ann Neurol 1977: 2:41-48.

26. Nagler B. Beebe GW, Kurtzke JF et al. Studies on the natural history of multiple sclerosis. I. Design and Diagnosis. Acta Neurol Scan 1966: 42: suppl 19: 141-156.

27. Thygesen $P$. The course of disseminated sclerosis. A close-up of 105 attacks. Copenhagen: Rosenkilde and Bagger. 1953.

28. Kurtzke JF. Symptomatology of Multiple Sclerosis. In: Vinken PJ. Brwyn GM, eds. Handbook of Neurology, Vol. 9. North-Holland Amsterdam: American Elseimier NY Publishing Company, 1970 179-209.

29. McAlpine D. Lumsden CE. Acheson ED. Symptoms and signs in multiple sclerosis. A reappraisal. 2nd ed. Edinburgh and London: Livingstone, 1972: 140.

30. Paty DW, Poser C. Peripheral Nerve Signs and Amyotrophy. In: Poser C, ed. The diagnosis of multiple sclerosis. Stuttgart, New York: Theime Stratton Inc, 1984: 39-40.

31. Fisher M, Long RR, Drachman DA. Amytrophy in multiple sclerosis: a pseudoneurogenic process. Trans Am Neurol Assoc. 1981: 10: 261-263.

32. Fisher $M$, Long RR, Drachman DA. Hand muscle atrophy in multiple sclerosis. Arch Neurol 1983; 40: 811-815.

33. Mulder DW. Clinical limits of ALS. In: Rowland LP, ed. Advances in Neurology. New York: Raven Press, 1982: 15-22.

34. Tyler HR. Non Familial Amyotrophy. In: Rowland LP, ed. Advances in Neurology. New York: Raven Press, 1982: 173-180.

35. Mulder DW, Bushek W, Spring E et al. Motor neuron disease (ALS): evaluation of detection thresholds of cutaneous sensation. Neurology (Cleveland) 1983; 33: 1625-1627.

36. Wechsler IS, Brock S, Weil A. Amyotrophic lateral sclerosis with objective and subjective (neuritic) sensory disturbances. Arch Neurol Psychiat 1929; 21: 299-310.

37. Feller TG, Jones RE, Netsky MG. Amyotrophic lateral sclerosis and sensory changes. Va Med 1966; 93: 328-335.

38. Noseworthy JH, Heffernan LP. Motor radiculopathy - an unusual presentation of multiple sclerosis. Canad J Neurol Sci 1980; 7: 207-209.

39. Breland AE, Currier RD. Multiple sclerosis and amyotrophic lateral sclerosis in Mississippi. Neurol 1967; 17: 1011-1016.

40. Juergens SM, Kurland LT, Okazaki H, Mulder DW. ALS in Rochester Minnesota, 1925-1977. Neurology 1980: 30: 463-470. 